\title{
Hsp110 expression changes in rat primary myocardial cells exposed to heat stress in vitro
}

\author{
Z.J. Liu ${ }^{1,2 *}$, Y.J. Lv ${ }^{1 *}$, M. Zhang ${ }^{3}$, Z.H. Yue ${ }^{1}$, S. Tang ${ }^{1}$, A. Islam ${ }^{1}$, \\ B. Rehana ${ }^{1}$, E.D. Bao ${ }^{1}$ and J. Hartung ${ }^{4}$ \\ ${ }^{1}$ Animal Pathology Laboratory, Department of Basic Veterinary, \\ College of Veterinary Medicine, Nanjing Agricultural University, \\ Nanjing, China \\ ${ }^{2}$ Animal Pathology Laboratory, Department of Animal and Plant Quarantine, \\ College of Animal Science and Technology, \\ Henan University of Science and Technology, Luoyang, China \\ ${ }^{3}$ College of Animal Science and Technology, Jinling Institute of Technology, \\ Nanjing, China \\ ${ }^{4}$ Institute for Animal Hygiene, Animal Welfare and Farm Animal Behaviour, \\ University of Veterinary Medicine Hannover, Foundation, Hannover, Germany \\ *These authors contribution is equal to this study. \\ Corresponding author: E.D. Bao \\ E-mail: b_endong@njau.edu.cn
}

Genet. Mol. Res. 11 (4): 4728-4738 (2012)

Received April 18, 2012

Accepted August 27, 2012

Published November 29, 2012

DOI http://dx.doi.org/10.4238/2012.November.29.1

\begin{abstract}
We investigated and described the kinetics of heat shock protein (Hsp) 110 expression and distribution in rat primary myocardial cells exposed to heat stress in vitro. After incubation at $37^{\circ} \mathrm{C}$ for $72 \mathrm{~h}$, myocardial cells were heat stressed at $42^{\circ} \mathrm{C}$ for $0,10,20$, 40, 60, 120, 240, 360, and $480 \mathrm{~min}$. Significant increases in aspartate transaminase, lactate dehydrogenase, and creatine kinase enzymatic activities in the myocardial cell culture media were observed during heat stress, suggesting that the integrity of the myocardial cells was altered. Immunocytochemical analysis revealed that the expressed Hsp110 was constitutively localized in the cytoplasm and in the nuclei
\end{abstract}


in small amounts characterized by a granular pattern. Nuclear Hsp110 levels increased significantly after $240 \mathrm{~min}$ of heat stress compared with levels in the control. The overall levels of Hsp110 expression increased significantly after $20 \mathrm{~min}$. After $240 \mathrm{~min}$, Hsp110 levels were approximately 1.2-fold higher than those in the control. Increasing levels of $h$ sp 110 messenger RNA detected using real-time quantitative polymerase chain reaction were observed after $20 \mathrm{~min}$ of heat stress, and the levels peaked with a 10 -fold increase after $240 \mathrm{~min}$ of heat stress. These results indicate that the expression of Hsp110 in primary myocardial cells in vitro is sensitive to hyperthermic stress and that Hsp110 is involved in the potential acquisition of thermotolerance after heat stress. Therefore, Hsp110 might play a fundamental role in opposing and alleviating heat-induced damage caused by hyperthermic stress in primary myocardial cells.

Key words: Heat shock protein 110; Expression; Heat stress; In vitro; Heat shock protein 110 messenger RNA; Primary myocardial cells of rat

\section{INTRODUCTION}

Heat shock proteins (Hsps) are protective proteins that are expressed conservatively in cells under unstressed conditions; however, expression levels rise significantly after exposure to heat shock or other types of stress, including environmental, physical, chemical, and transport stress (Barisic and Kopic, 2002). Hsps perform important roles in the regulation of essential cell functions, such as protein translocation, refolding, and assembly. Hsps can be divided into six families of sequence-related proteins according to their molecular size, structure, and function: the small Hsps, Hsp40, Hsp60, Hsp70, Hsp90, and Hsp110 (Lindquist and Craig, 1988).

Hsp70, which is expressed in the vertebrae, heart, and brain, is one of the most extensively studied Hsps. Although previous studies have reported that Hsp110 is an important divergent subgroup of the Hsp70 family and it has been long recognized as one of the primary heat shock proteins in mammalian cells, its protective role is obviously different from Hsp70. Hsp110 can also reportedly express a great deal from the proliferating zone to the hypertrophic zone in young rats (Vanmuylder et al., 1997). Furthermore, Hsp110 plays an important role in neuronal dysfunction caused by transient forebrain ischemia. Hsp110 is a strong immunoadjuvant in response to cancer; recombinant Hsp110 and antigen proteins can form anti-tumor vaccine complexes. Recently, Hsp110 has been shown to act as a nucleotide exchange factor for the molecular chaperone Hsp70 and stabilize unfolded proteins for subsequent protein refolding in yeast (Polier et al., 2010). However, Hsp110 has only recently begun to be studied (Chen et al., 1996).

The heart is one of the most important organs in the body, and it carries out varied physiological functions. Lethal pathological symptoms, such as cardiac failure and cardiac stroke, result from heart damage caused by a variety of different factors such as heat, chemicals, transport (in animals), physiological dysfunction, and ischemic heart disease (Gisolfi et al., 1991). Such stress factors can lead to sudden death in humans and animals owing to the cardiac dysfunction induced by heart damage (Hobbesland et al., 1997). Generous research data have verified that heat stress can cause lethal heart injury or damage (Rai and Ambwany, 
1980; Gathiram et al., 1987, 1988). Increases in Hsps induced by some stresses including heat and ischemia can also reportedly protect cardiac muscle cells from severe stress (Cumming et al., 1996; Morris et al., 1996).

Hsp110 can protect cellular and molecular targets from heat damage (Oh et al., 1997). However, little is known about the expression of Hsp110 in response to high temperatures. Therefore, investigating the changes in Hsp110 expression after heat stress as well as the potential protective role of Hsp110 against hyperthermia-induced cellular damage is essential. The purpose of this study was to understand the kinetics of Hsp110 expression in rat primary myocardial cells exposed to various durations of heat stress in vitro.

\section{MATERIAL AND METHODS}

\section{Cell culture and heat stress treatment}

Rat primary myocardial cells were provided by Shanghai Fu Meng Biological Technology, Ltd. Two-day-old neonatal rats were killed, and their hearts were removed under sterile conditions. Blood cells were washed away, and the tissue was fragmented by cutting it into shreds with scissors in sterile D-Hanks solution. The myocardial tissue was then digested with $1 \mathrm{mg} / \mathrm{mL}$ collagenase (type I) solution (17100-017, Gibco, USA) at $37^{\circ} \mathrm{C}$ for $15 \mathrm{~min}$. Digestion was terminated with the Dulbecco's modified Eagle's medium (DMEM; 11995-065, Gibco) supplemented with $20 \%$ fetal bovine serum (FBS; 16141079, Gibco) and centrifugation at $1000 \mathrm{rpm}$ for 10 min. The pellet was resuspended in DMEM supplemented with $20 \%$ FBS and grown on cell culture plates (430165, Corning, USA) containing DMEM supplemented with 20\% FBS, $100 \mathrm{U} /$ $\mathrm{mL}$ penicillin, and $100 \mu \mathrm{g} / \mathrm{mL}$ streptomycin (Boster, China) in a humidified atmosphere of 5\% $\mathrm{CO}_{2}$ and $95 \%$ air at $37^{\circ} \mathrm{C}$. The cells were transferred to new cell culture plates at a density of 4-6 x $10^{6}$ cells per $35-\mathrm{mm}^{2}$ plate. 5-Bromo-2'-deoxyuridine (B16880, Sigma, Germany) solution was added to the medium after $1 \mathrm{~h}$ and cultivated for $72 \mathrm{~h}$ to allow the cells to adapt. When a minimum of $90 \%$ of the cells in the culture plates were alive, the cultures were divided into 9 groups: the control group and 8 groups exposed to heat stress for 10, 20, 40, 60, 120, 240, 360, and 480 $\mathrm{min}$. Exposure to heat stress was achieved by quickly transferring the groups to be stressed into an adjacent incubator with a humidified atmosphere of $5 \% \mathrm{CO}_{2}$ and $95 \%$ air at $42^{\circ} \mathrm{C}$.

\section{Enzymatic activities in myocardial cell media}

Media from myocardial cell cultures were collected from the heat stress and control groups and stored at $-80^{\circ} \mathrm{C}$. The activities for aspartate aminotransferase (AST), lactate dehydrogenase (LDH), and creatine kinase (CK) in all medium samples were measured according to the instructions provided in commercial kits (Jiancheng, China).

\section{Immunofluorescence}

Myocardial cells (2-6 x $10^{6}$ cells in $35-\mathrm{mm}^{2}$ plates) grown on glass coverslips coated with polylysine were fixed with $4 \%$ paraformaldehyde for $30 \mathrm{~min}$ at room temperature and permeabilized with $0.4 \%$ Triton X-100 in phosphate-buffered saline (PBS). After blocking with 5\% skim milk in PBS for $1 \mathrm{~h}$, a 1:200 dilution of anti-rat Hsp110 monoclonal antibody (610510, BD, USA) was 
added to the coverslip and incubated in a moist chamber for $1 \mathrm{~h}$ at $37^{\circ} \mathrm{C}$. After three washes with PBS, the coverslips were incubated with rhodamine red-conjugated goat anti-mouse immunoglobulin $\mathrm{G}$ antibody at a 1:50 dilution (BA1089, Boster) at $37^{\circ} \mathrm{C}$ for $1 \mathrm{~h}$. After another wash with PBS, the coverslips were dyed with 4',6-diamidino-2-phenylindole (H-1000, Vector, USA) solution. Myocardial cells were observed using an immunofluorescence microscope (Cx41-32rfl, Olympus, Japan).

\section{Western blot}

After heat stress at $42^{\circ} \mathrm{C}$, myocardial cells were washed with $0.01 \mathrm{M}$ PBS, $\mathrm{pH} 7.4$, and lysed with 200 or $300 \mu \mathrm{L}$ M-Per protein extraction reagent (78501, Thermo, USA) supplemented with 2 or $3 \mu \mathrm{L}$ Halt protease inhibitor mixture (Thermo, 78430). Lysates of myocardial cells were collected and centrifuged at 14,000 $\mathrm{g}$ for $10 \mathrm{~min}$, and the supernatant was retained. Then, protein concentration was determined using a BCA kit (23235, Thermo). Bromophenol loading buffer $(10 \mu \mathrm{L})$ was added to $50-\mu \mathrm{L}$ protein samples, mixed well, boiled for $10 \mathrm{~min}$, and cooled. Equal amounts of protein $(10 \mu \mathrm{g})$ were subjected to $10 \%$ sodium dodecyl sulfate polyacrylamide gel electrophoresis $(110 \mathrm{~V}, 2 \mathrm{~h})$ and transferred onto nitrocellulose membranes via electrotransfer ( $300 \mathrm{~mA}, 2 \mathrm{~h}$ ). The membranes were blocked with 5\% non-fat milk in Tris-buffered saline (20 $\mathrm{mM}$ Tris- $\mathrm{HCl}, \mathrm{pH} 7.6,137 \mathrm{mM} \mathrm{NaCl}$ ) containing $0.1 \%$ Tween- 20 for $2 \mathrm{~h}$ at room temperature. The membrane was then incubated with anti-rat Hsp110 monoclonal antibody (610510, BD) at a 1:2500 dilution and anti-rat $\beta$-actin monoclonal antibody (ab8224, Abcam, USA) at a 1:1000 dilution for $16 \mathrm{~h}$ at $4{ }^{\circ} \mathrm{C}$. After being washed with Tris-buffered saline containing Tween 20, the membrane was further incubated with peroxidase-conjugated goat anti-mouse immunoglobulin G antibody (BA1038; Boster) at a 1:5000 dilution at $37^{\circ} \mathrm{C}$ for $2 \mathrm{~h}$. The antibody-antigen complexes were detected using SuperSignal West Pico Chemiluminescent Substrate (34080; Thermo). The bands on the developed film were quantified with the Quantity One 4.6.2 software (Bio-Rad, USA). The density of each band was normalized to that of $\beta$-actin protein.

\section{Detection of $h$ sp110 mRNA with real-time fluorescence quantitative PCR (qPCR)}

\section{Design of qPCR primers}

Primer sets were specifically designed to anneal to each target mRNA. The sequences of hsp110 and $\beta$-actin mRNAs were obtained from the National Center for Biotechnology Information GenBank (accession Nos. BC081945.1 and NM_031144.2, respectively). The primers were designed using the Primer Premier 5.0 software for conventional and qPCR amplification. Primer sequences for these genes were as follows:

$h s p 110$ sense: 5'-GCGTGGAGCAGATAACA-3'; hsp 110 antisense: 5'-AAGCAACAG CCGTCTA-3'. The expected size of the PCR product was $198 \mathrm{bp}$. $\beta$-actin sense: 5'-TGCTCCTC CTGAGCGCAAGT-3'; $\beta$-actin antisense: 5'-ACGCAGCTCAGTAACAGTCCGC-3'. The expected size of the PCR product was $161 \mathrm{bp}$.

\section{Isolation of total RNA and reverse transcription}

After being heat stressed at $42^{\circ} \mathrm{C}$, myocardial cells were washed with PBS, and total RNA was isolated using the TRIZOL reagent (15596-026; Invitrogen, USA) according to manufacturer 
instructions. The concentration of RNA was determined using a spectrophotometer (Mx3000P; Stratagene, USA) at $260 \mathrm{~nm}$. Serial dilutions of RNA were prepared with ribonuclease-free water, and $2 \mu \mathrm{g}$ of each sample was synthesized into DNA using a Transcript M-MLV kit (28025013, Gibco) following the manufacturer protocol. Reaction products were stored at $-80^{\circ} \mathrm{C}$.

\section{$q P C R$}

Each DNA sample ( $2 \mu \mathrm{L}, 25 \mathrm{X}$ dilution) was suspended in 2X SYBR Premix Ex Taq (DRR041S, Takara, China) with primers ( 25 pmol sense and antisense primers) and doubledistilled water to a total volume of $25 \mu \mathrm{L}$. qPCR was performed using an ABI $7300 \mathrm{qPCR}$ thermocycler (7300, Applied Biosystems, USA). The thermal profile was established according to the manufacturer protocol. Briefly, enzyme activation was carried out at $95^{\circ} \mathrm{C}$ for $3 \mathrm{~min}$ followed by 40 cycles of denaturation at $95^{\circ} \mathrm{C}$ for $5 \mathrm{~s}$ and annealing and elongation at $53^{\circ} \mathrm{C}$ for $30 \mathrm{~s}$. For each run, a negative control tube without DNA was analyzed along with the experimental samples. A 2-fold dilution series of the template was used in the qPCRs to obtain two standard curves as follows: the target, $h s p 110$ mRNA: $\mathrm{Y}=-3.299 \log (\mathrm{x})+36.19, \mathrm{r}^{2}=0.998$, and the reference, $\beta$-actin mRNA: $\mathrm{Y}=-3.310 \log (\mathrm{x})+26.86, \mathrm{r}^{2}=0.997$. The amplification efficiencies of the target and reference were approximately equal. Therefore, the $h s p 110 \mathrm{mRNA}$ levels were normalized using the following formula:

$$
\begin{gathered}
\text { Relative quantity of hsp110 mRNA }=2^{-\Delta \Delta \mathrm{Ct}} \\
\Delta \Delta \mathrm{Ct}=\left[\left(\mathrm{Ct}_{\text {hsp I10 mRNA }}-\mathrm{Ct}_{\beta \text {-actin mRNA }}\right) \text { control group }\right]-\left[\left(\mathrm{Ct}_{\text {hsp110mRNA }}-\mathrm{Ct}_{\beta \text {-actin mRNA }}\right) \text { test group }\right]
\end{gathered}
$$

\section{Statistical analysis}

Statistical analyses of the differences between the heat-stressed groups and the control group were performed with one-way analysis of variance followed by the least significant difference multiple comparison test provided by SPSS version 17.0 for Windows (SPSS statistics 17.0, IBM, USA). Results are reported as means \pm standard deviation for at least three independent experiments. P values of $<0.05$ were considered to be statistically significant.

\section{RESULTS}

\section{AST, LDH, and CK levels in culture media}

Studies have shown that the diversity of AST, LDH, and CK enzymes often foreshadow the changes of cellular structure induced by heat shock - for example, during the transportation of pigs (Bao et al., 2009). Whether AST, LDH, and CK levels change in response to heat stress in rat primary myocardial cells in vitro remains to be determined. To explore this question, we detected AST, LDH, and CK levels in the supernatant of primary myocardial cells. The levels of these enzymes measured in the media of primary myocardial cell cultures are shown in Table 1. The AST activities in the media of the heat-stressed groups were significantly higher $(\mathrm{P}<0.01)$ than those in the media of the control. A significant increase $(\mathrm{P}<0.05)$ in LDH activity was observed only at 20 and $480 \mathrm{~min}$ of heat stress. The level of CK activity increased significantly $(\mathrm{P}<0.05)$ at $120 \mathrm{~min}$ of heat stress and then decreased gradually after $240 \mathrm{~min}$ of heat stress. 
Table 1. Activity level of aspartate aminotransferase (AST), lactate dehydrogenase (LDH) and creatine kinase $(\mathrm{CK})$ in the primary myocardial cell media (U/L).

\begin{tabular}{|c|c|c|c|c|c|c|c|c|c|}
\hline & \multirow{2}{*}{$\begin{array}{c}\text { Control } \\
\text { group } \\
0 \mathrm{~min}\end{array}$} & \multicolumn{8}{|c|}{ Heat stress group } \\
\hline & & $10 \mathrm{~min}$ & $20 \mathrm{~min}$ & $40 \mathrm{~min}$ & $60 \mathrm{~min}$ & $120 \mathrm{~min}$ & $240 \mathrm{~min}$ & $360 \mathrm{~min}$ & $480 \mathrm{~min}$ \\
\hline$\overline{\mathrm{AST}}$ & $16.45 \pm 0.55$ & $29.2 \pm 1.10^{\mathrm{a}}$ & $21.15 \pm 1.05^{\mathrm{a}}$ & $27.40 \pm 2.50^{\mathrm{a}}$ & $32.78 \pm 1.13^{\mathrm{a}}$ & $27.35 \pm 1.25^{\mathrm{a}}$ & $31.35 \pm 4.05^{\mathrm{a}}$ & $33.05 \pm 2.95^{\mathrm{a}}$ & $35.0 \pm 0.80^{\mathrm{a}}$ \\
\hline LDH & $51.5 \pm 11.5$ & $57.5 \pm 8.50$ & $67.5 \pm 4.50^{\mathrm{b}}$ & $60.50 \pm 12.50$ & $64.0 \pm 4.0$ & $61.0 \pm 10.0$ & $64.50 \pm 4.50$ & $59.50 \pm 5.50$ & $68.67 \pm 1.52^{\mathrm{b}}$ \\
\hline $\mathrm{CK}$ & $1.50 \pm 0.50$ & $2.50 \pm 0.50$ & $3.50 \pm 0.50$ & $3.50 \pm 1.50$ & $4.50 \pm 2.50$ & $5.50 \pm 2.50^{\mathrm{a}}$ & $4.0 \pm 2.0$ & $4.0 \pm 1.0$ & $4.0 \pm 1.0$ \\
\hline
\end{tabular}

Data are reported as means \pm standard deviation for three plates in each group. ${ }^{\text {aValues differ significantly from the }}$ control group $(\mathrm{P}<0.05)$; ${ }^{\mathrm{b}}$ values differ significantly from the control group $(\mathrm{P}<0.01)$.

\section{Localization of Hsp110 in primary myocardial cells}

Immunocytochemical staining of Hsp110 in primary myocardial cells is shown in Figure 1. Hsp110 was consistently present in cardiac muscle cells in both the experimental and control groups. Hsp110 displayed predominantly cytoplasmic staining; however, some Hsp110 staining was also observed in the nuclei of myocardial cells in the control group. After 60 min of heat stress, a larger amount of nuclear Hsp110 staining was observed. The most conspicuous Hsp110 staining was observed after 240 min of heat stress. Abundant Hsp110 staining was observed in the cytoplasm.

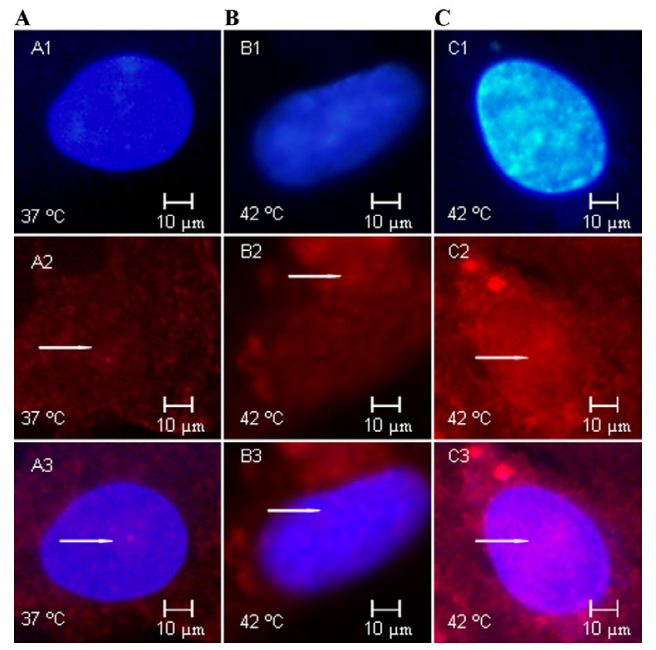

Figure 1. Intracellular localization of Hsp110 in rat primary myocardial cells in response to heat stress at $42^{\circ} \mathrm{C}$ in vitro. Myocardial cells were maintained at $37^{\circ} \mathrm{C}(\mathbf{A})$, and $60 \mathrm{~min}(\mathbf{B})$ and $120 \mathrm{~min}(\mathbf{C})$ of heat stress at $42^{\circ} \mathrm{C}$. Hsp 110 was detected with monoclonal antibody and TRITC (red) secondary antibody conjugate as described in Material and Methods, while nuclei were stained with DAPI (blue). A. Normal control: 1. The nucleus was stained with DAPI (blue); 2. Many Hsp110 stained granules (red) throughout the cell; 3. Only a few Hsp110 stained granules (red) appearing in the nucleus. B. Heat-stressed group of 60 min: 1. The nucleus was stained with DAPI (blue); 2. Many Hsp110 stained granules (red) throughout the cell; 3. Only a few Hsp110 stained granules (red) throughout the nucleus. C. Heat-stressed group of 240 min: 1. The nucleus was stained with DAPI (blue); 2. Many Hsp110 stained granules (red) throughout the cell, which are more than that of normal control and heat-stressed group of $60 \mathrm{~min}$; 3. The Hsp110 stained granules entering into the nucleus are more than in groups A and B. Scale bar $=10 \mu \mathrm{m}$ ( $400 \mathrm{X}$ magnification). 


\section{Levels of Hsp110 protein and mRNA in myocardial cells}

As shown in Figure 2, Hsp110 expression increased gradually after 10 min of heat stress at $42^{\circ} \mathrm{C}$. However, Hsp110 expression significantly increased $(\mathrm{P}<0.01)$ at $120 \mathrm{~min}$ of heat stress and reached peak levels at 480 min of heat stress. The highest level of Hsp110 was approximately 1.2-fold higher than that of the control.

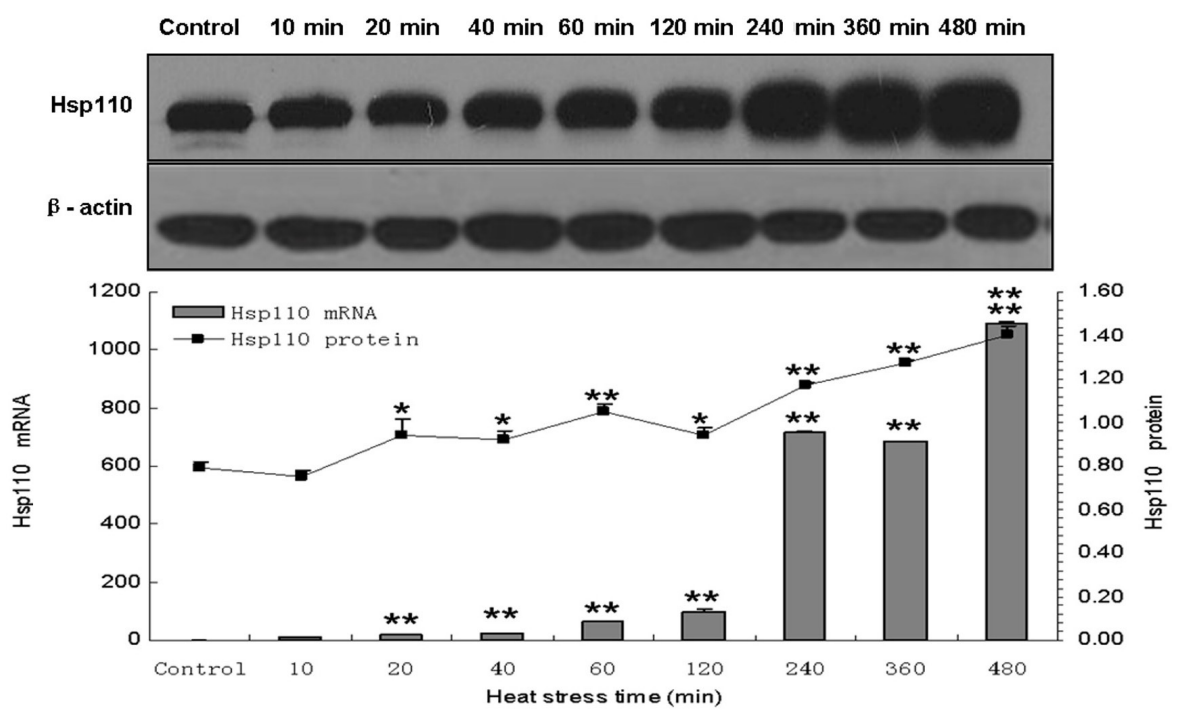

Figure 2. Relative levels of the Hsp110 protein and $h s p 110 \mathrm{mRNA}$ in myocardial cells in response to hyperthermia at $42^{\circ} \mathrm{C}$ in vitro. Figures represent Western blot and qPCR analysis of the Hsp110 protein and hsp110 mRNA; $\beta$-actin and $\beta$-actin mRNA were used as an internal control. The relative induction level of Hsp110 was obviously low compared to control at the beginning of heat stress (10 min), then Hsp110 rose gradually between 20 and 480 min of heat stress at $42^{\circ} \mathrm{C}$. In addition, the increase in levels of Hsp110 between 240 and 480 min was significant $(\mathrm{P}<0.01)$. However, the relative levels of hsp110 mRNA increased at the beginning of heat stress at $42^{\circ} \mathrm{C}$; the amplification levels of hsp110 mRNA were significant $(\mathrm{P}<0.01)$ between 20 and $480 \mathrm{~min}$ at $42^{\circ} \mathrm{C}$. Data are reported as means \pm standard deviation for 3 separate experiments in each group. ${ }^{*} \mathrm{P}<0.05$ for significant differences between the stressed group and the normal control group; $* * \mathrm{P}<0.01$ for significant differences between the stressed group and the normal control group.

The level of hsp110 mRNA increased significantly $(\mathrm{P}<0.05)$ after 10 min of heat stress compared with that in controls, and the level of hsp 110 mRNA increased rapidly between 240 and $480 \mathrm{~min}$ of heat stress. The hsp110 mRNA level peaked at $480 \mathrm{~min}$ and was nearly 10 -fold higher than that in the treatment groups at durations shorter than 240 min.

\section{DISCUSSION}

Heat stress modifies cellular proteins and may be involved in intracellular structural alterations. Therefore, the integrity of cellular structures may be altered during heat shock (Yu et al., 2008). The presence of AST, LDH, and CK enzymatic activity in intercellular fluid is often associated with heart disease (Koelkebeck and Odom, 1995; Mitchell and Sandercock, 
1995). These enzymes can be used as molecular predictors to evaluate damage to cardiac muscle cells during heat stress (Haagensen et al., 2008). The enzymatic activities of AST and LDH have been evaluated as indicators of stress during transportation, and acute cellular lesions have been observed through histopathological examination of the hearts of transported pigs (Bao et al., 2008). In the present study, AST, LDH, and CK activities were significantly increased after heat stress compared with those in unstressed myocardial cells, suggesting that heat stress injured cardiac muscle cells from the start of heat stress $(10 \mathrm{~min})$ at $42^{\circ} \mathrm{C}$. Although the distinct mechanisms are not yet well understood, the cell culture-based heat stress model used in these experiments may be a helpful tool to elucidate further the relationship between enzymatic activity induction and cardiac tissue damage.

Hsps are important endogenous protective proteins that play a significant role in the cellular response to stress (Gullo and Teoh, 2004). Most Hsps provide a mechanism to prevent damage caused by misfolded, damaged, and aggregated proteins (Lei et al., 2009). In the present study, Hsp110 was characterized for the first time for its intracellular localization and expression in vitro in the primary myocardial cells of neonatal rats under normal and heat-stressed conditions. Hsp110 was localized to the cytoplasm with slight enrichment in the nuclei under stressed conditions. These results were consistent with those of previous reports of the localization of Hsp110 family members in both the nucleus and the cytoplasm (Easton et al., 2000). Our immunocytochemical analysis indicated that Hsp110 expression increased gradually with increased time under stress compared with that in the control. Western blot analysis of Hsp110 protein levels in primary myocardial cells confirmed this result. In mammalian cells, Hsp expression increases in response to various stresses, and Hsps act as molecular chaperones under physiological conditions (Evrard et al., 1999). In a previous study, Hsp110 was induced in renal murine inner medullary collecting duct epithelial cells in an analysis of mRNA expression after heat shock (Santos et al., 1998). In our present study, qPCR results showed that the levels of hsp 110 mRNA were generally induced during the heat stress treatment, which was positively associated with increased Hsp110 protein expression after heat stress. These observations are consistent with the classic regulatory mechanisms of Hsp transcription and translation. Evidence presented in previous studies has also indicated that the accumulation of Hsp proteins depends on the stable accumulation of large quantities of their corresponding mRNAs (DiDomenico et al., 1982; Burdon, 1987).

Most cells increase Hsp expression in response to stress (Locke et al., 1995) or exposure to high temperatures (Lindquist and Petersen, 1990). Overexpression of Hsp110 confers substantial heat resistance and protects cells and proteins from thermal damage by efficiently recognizing denatured proteins (Hylander et al., 2000). In the present study, the enzymatic activity of CK decreased after 240 min of heat stress at $42^{\circ} \mathrm{C}$, which suggested that heat-induced damage to primary myocardial cells might be alleviated. Furthermore, 240 min of hyperthermic stress resulted in $h s p 110$ mRNA levels that were nearly 10 -fold higher than those resulting from 10-120 min of heat stress. Interestingly, Hsp110 protein levels after 240 min of heat stress were approximately 1.2-fold higher than those that occurred at durations of heat stress shorter than $120 \mathrm{~min}$.

Hsps are synthesized in response to increased temperature, and they repair or degrade damaged proteins as a defense strategy to ensure cell survival (Ciocca et al., 1993; Harrington et al., 1994; Benjamin and McMillan, 1998). In addition, Hsps are encoded by heat shock genes, and the induction of these genes is largely regulated at the transcriptional level (Kaarni- 
ranta et al., 2002). These observations indicate that Hsp110 helps protect cells from damage, suggesting that Hsp110 might play a comparatively fundamental role in opposing the damage caused by hyperthermic stress. In fact, compared with Hsp70, Hsp110 is more efficient at binding to and stabilizing denatured protein substrates (Kaneko et al., 1997; Yam et al., 2005). Hsp110 is an efficient nucleotide exchange factor for both of the yeast cytosolic Hsp70s, Ssa1p and Ssb1p (Liu and Hendrickson, 2007), indicating that Hsp110 is an important regulator of Hsp70-substrate interaction (Dragovic et al., 2006; Raviol et al., 2006). Furthermore, Hsp110 uses a unique binding mode (Andreasson et al., 2008a,b) including the coupled effects of the nucleotides and interactions on the open-closed isomerization of the nucleotide binding domains (Mandal et al., 2010). Purified Hsp25, Hsp70, and Hsp110 spontaneously form a large complex (Wang et al., 2000) and act as a co-chaperone machine to maintain cellular structures (Manjili et al., 2003). All Hsp110 loss-of-function or deletion mutants listed in the Drosophila deletion project database are lethal (Easton et al., 2000). However, contrary to our finding of Hsp110 protecting myocardial cells from damage, Hsp110 expression is induced by cadmium exposure but is dispensable for cell survival of mouse NIH3T3 fibroblasts (Ridley et al., 2010), suggesting that the regulation of Hsp110 may have cellular and tissue specificity in disparate organisms (Zhu et al., 2009; Yue et al., 2010).

\section{ACKNOWLEDGMENTS}

Research supported by the National Natural Science Foundation of China (\#30972165, \#30430420), the National Department Public Benefit Research Foundation (Agriculture) (\#201003060-11), the Project Fund by the Priority Academic Program Development of Jiangsu Higher Education Institutions (PAPD), and the Sino-German Agricultural Cooperation Project of the Federal Ministry of Food, Agriculture and Consumer Production, Berlin, Germany.

\section{Conflict of interests}

The authors declared that no conflict of interests exists.

\section{REFERENCE}

Andreasson C, Fiaux J, Rampelt H, Druffel-Augustin S, et al. (2008a). Insights into the structural dynamics of the Hsp110Hsp70 interaction reveal the mechanism for nucleotide exchange activity. Proc. Natl. Acad. Sci. U. S. A. 105: 1651916524.

Andreasson C, Fiaux J, Rampelt H, Mayer MP, et al. (2008b). Hsp110 is a nucleotide-activated exchange factor for Hsp70. J. Biol. Chem. 283: 8877-8884.

Bao E, Sultan KR, Nowak B and Hartung J (2008). Expression and distribution of heat shock proteins in the heart of transported pigs. Cell Stress Chaperones 13: 459-466.

Bao E, Sultan KR, Bernhard N and Hartung J (2009). Expression of heat shock proteins in tissues from young pigs exposed to transport stress. Dtsch. Tierarztl. Wochenschr. 116: 321-325.

Barisic K and Kopic J (2002). Heat shock proteins and their clinical relevance. Acta Pharm. 52: 71-82.

Benjamin IJ and McMillan DR (1998). Stress (heat shock) proteins: molecular chaperones in cardiovascular biology and disease. Circ. Res. 83: 117-132.

Burdon RH (1987). Temperature and animal cell protein synthesis. Symp. Soc. Exp. Biol. 41: 113-133.

Chen X, Easton D, Oh HJ, Lee-Yoon DS, et al. (1996). The $170 \mathrm{kDa}$ glucose regulated stress protein is a large HSP70-, HSP110-like protein of the endoplasmic reticulum. FEBS Lett. 380: 68-72.

Ciocca DR, Oesterreich S, Chamness GC, McGuire WL, et al. (1993). Biological and clinical implications of heat shock 
protein 27,000 (Hsp27): a review. J. Natl. Cancer Inst. 85: 1558-1570.

Cumming DV, Heads RJ, Brand NJ, Yellon DM, et al. (1996). The ability of heat stress and metabolic preconditioning to protect primary rat cardiac myocytes. Basic Res. Cardiol. 91: 79-85.

DiDomenico BJ, Bugaisky GE and Lindquist S (1982). The heat shock response is self-regulated at both the transcriptional and posttranscriptional levels. Cell 31: 593-603.

Dragovic Z, Broadley SA, Shomura Y, Bracher A, et al. (2006). Molecular chaperones of the Hsp110 family act as nucleotide exchange factors of Hsp70s. EMBO J. 25: 2519-2528.

Easton DP, Kaneko Y and Subjeck JR (2000). The hsp110 and Grp1 70 stress proteins: newly recognized relatives of the Hsp70s. Cell Stress Chaperones 5: 276-290.

Evrard L, Vanmuylder N, Dourov N, Glineur R, et al. (1999). Cytochemical identification of HSP110 during early mouse facial development. J. Craniofac. Genet. Dev. Biol. 19: 24-32.

Gathiram P, Gaffin SL, Brock-Utne JG and Wells MT (1987). Time course of endotoxemia and cardiovascular changes in heat-stressed primates. Aviat. Space Environ. Med. 58: 1071-1074.

Gathiram P, Wells MT, Raidoo D, Brock-Utne JG, et al. (1988). Portal and systemic plasma lipopolysaccharide concentrations in heat-stressed primates. Circ. Shock 25: 223-230.

Gisolfi CV, Matthes RD, Kregel KC and Oppliger R (1991). Splanchnic sympathetic nerve activity and circulating catecholamines in the hyperthermic rat. J. Appl. Physiol. 70: 1821-1826.

Gullo CA and Teoh G (2004). Heat shock proteins: to present or not, that is the question. Immunol. Lett. 94: 1-10.

Haagensen L, Jensen DH and Gesser H (2008). Dependence of myosin-ATPase on structure bound creatine kinase in cardiac myofibrils from rainbow trout and freshwater turtle. Comp Biochem. Physiol. A Mol. Integr. Physiol. 150: 404-409.

Harrington HM, Dash S, Dharmasiri N and Dharmasiri S (1994). Heat-shock proteins: a search for functions. Aust. J. Plant Physiol. 21: 843-855.

Hobbesland A, Kjuus H and Thelle DS (1997). Mortality from cardiovascular diseases and sudden death in ferroalloy plants. Scand. J. Work Environ. Health 23: 334-341.

Hylander BL, Chen X, Graf PC and Subjeck JR (2000). The distribution and localization of hsp110 in brain. Brain Res. 869: 49-55.

Kaarniranta K, Oksala N, Karjalainen HM, Suuronen T, et al. (2002). Neuronal cells show regulatory differences in the hsp70 gene response. Brain Res. Mol. Brain Res. 101: 136-140.

Kaneko Y, Nishiyama H, Nonoguchi K, Higashitsuji H, et al. (1997). A novel hsp110-related gene, apg-1, that is abundantly expressed in the testis responds to a low temperature heat shock rather than the traditional elevated temperatures. $J$. Biol. Chem. 272: 2640-2645.

Koelkebeck KW and Odom TW (1995). Laying hen responses to acute heat stress and carbon dioxide supplementation: II. Changes in plasma enzymes, metabolites and electrolytes. Comp. Biochem. Physiol. A Physiol. 112: 119-122.

Lei L, Yu J and Bao E (2009). Expression of heat shock protein 90 (Hsp90) and transcription of its corresponding mRNA in broilers exposed to high temperature. Br. Poult. Sci. 50: 504-511.

Lindquist S and Craig EA (1988). The heat-shock proteins. Annu. Rev. Genet. 22: 631-677.

Lindquist S and Petersen R (1990). Selective translation and degradation of heat-shock messenger RNAs in Drosophila. Enzyme 44: 147-166.

Liu Q and Hendrickson WA (2007). Insights into Hsp70 chaperone activity from a crystal structure of the yeast Hsp110 Sse1. Cell 131: 106-120.

Locke M, Noble EG, Tanguay RM, Feild MR, et al. (1995). Activation of heat-shock transcription factor in rat heart after heat shock and exercise. Am. J. Physiol. 268: C1387-C1394.

Mandal AK, Gibney PA, Nillegoda NB, Theodoraki MA, et al. (2010). Hsp1 10 chaperones control client fate determination in the hsp70-Hsp90 chaperone system. Mol. Biol. Cell 21: 1439-1448.

Manjili MH, Wang XY, Chen X, Martin T, et al. (2003). HSP110-HER2/neu chaperone complex vaccine induces protective immunity against spontaneous mammary tumors in HER-2/neu transgenic mice. J. Immunol. 171: 4054-4061.

Mitchell MA and Sandercock DA (1995). Increased hyperthermia induced skeletal muscle damage in fast growing broiler chickens? Poultry Sci. 74: 74.

Morris SD, Cumming DV, Latchman DS and Yellon DM (1996). Specific induction of the 70-kD heat stress proteins by the tyrosine kinase inhibitor herbimycin-A protects rat neonatal cardiomyocytes. A new pharmacological route to stress protein expression? J. Clin. Invest 97: 706-712.

Oh HJ, Chen X and Subjeck JR (1997). Hsp1 10 protects heat-denatured proteins and confers cellular thermoresistance. J. Biol. Chem. 272: 31636-31640.

Polier S, Hartl FU and Bracher A (2010). Interaction of the Hsp110 molecular chaperones from S. cerevisiae with substrate protein. J. Mol. Biol. 401: 696-707. 
Rai UC and Ambwany P (1980). Cardiovascular changes during varied thermal stress. Indian J. Physiol. Pharmacol. 24: 119-125.

Raviol H, Sadlish H, Rodriguez F, Mayer MP, et al. (2006). Chaperone network in the yeast cytosol: Hsp110 is revealed as an Hsp70 nucleotide exchange factor. EMBO J. 25: 2510-2518.

Ridley W, Nishitai G and Matsuoka M (2010). HSP110 expression is induced by cadmium exposure but is dispensable for cell survival of mouse NIH3T3 fibroblasts. Environ. Toxicol. Pharmacol. 29: 260-265.

Santos BC, Chevaile A, Kojima R and Gullans SR (1998). Characterization of the Hsp110/SSE gene family response to hyperosmolality and other stresses. Am. J. Physiol. 274: F1054-F1061.

Vanmuylder N, Evrard L and Dourov N (1997). Strong expression of heat shock proteins in growth plate cartilage, an immunohistochemical study of HSP28, HSP70 and HSP110. Anat. Embryol. 195: 359-362.

Wang XY, Chen X, Oh HJ, Repasky E, et al. (2000). Characterization of native interaction of hsp110 with hsp25 and hsc70. FEBS Lett. 465: 98-102.

Yam AY, Albanese V, Lin HT and Frydman J (2005). Hsp110 cooperates with different cytosolic HSP70 systems in a pathway for de novo folding. J. Biol. Chem. 280: 41252-41261.

Yu J, Bao E, Yan J and Lei L (2008). Expression and localization of Hsps in the heart and blood vessel of heat-stressed broilers. Cell Stress Chaperones 13: 327-335.

Yue Z, Hao Q, Tang S, Bao E, et al. (2010). Variation in Hsp90, HSF-1, and hsp90 mRNA expression in tissues of pigs exposed to different durations of transport. Livestock Sci. 129: 141-145.

Zhu L, Bao E, Zhao R and Hartung J (2009). Expression of heat shock protein 60 in the tissues of transported piglets. Cell Stress Chaperones 14: 61-69. 